\title{
THE TAXABLE TRANSACTION IN CONSUMERS' TAXES
}

\author{
Sherman P. Cohen*
}

Of the many problems that arise in the determination of the taxable transaction in consumers' taxes, this paper is devoted mainly to those which have reached the courts. ${ }^{1}$ Two consumers' taxes in particular are stressed; the sales tax, and its variant, the retailers' occupation tax. The matters discussed herein will, however, find an appreciable application in most other consumers' taxes.

A typical sales tax provision provides that "a tax is hereby levied on each retail sale of tangible personal property." Under such a provision, three main problems arise in the determination of the taxable transaction: First, what is a "sale"? Second, what is a "retail sale"? Third, what is "tangible personal property"? The first and third of these problems are discussed in this paper. The second problem, to which these are antecedent, is discussed in the next succeeding article. ${ }^{3}$

The common law has, of course, a long tradition in the definition of each of these terms. Definitions of the word "sale" are found especially in cases under the Statute of Frauds, and under the Uniform Sales Act. The tax cases have, it is true, uniformly declared that it is to the definition contained in the taxing statute, rather than to the common-law tradition, that one must first turn to determine whether a given activity is taxable. But what courts say and how they react are two different things. The ensuing discussion will reveal that the common law is still valuable as a key to judicial interpretation of the statutory definition.

\section{The Meaning of Sale}

\section{Sale v. Service}

In the law of sales a distinction is drawn between the sale of goods and the furnishing of services. ${ }^{4}$ This distinction lies at the basis of many of the sales tax cases. While some few statutes specifically include certain limited types of services, ${ }^{5}$

* A.B., I939, J.D., 194r, University of Chicago.

${ }^{1}$ For other discussions see Philipsborn, Illinois Supreme Court and the Retailers' Occupation Tax (1937) 31 Irl. L. Rev. 741, (1938) 32 id. 685; Note, Applicability of the Sales Tax to Particular Transactions (1938) 23 WAsH. U. L. Q. 399; Jacoby, Conflicting Interpretations of Retail Sales Tax Laws (1934) 2 U. of Chi. L. Rev. 78; Haig and Shoup, The Sales Tax in the American States (1934); (I938) 5 I Harv. L. Rev. 753, ix So. Calip. L. Rev. 532.

2 OHO CODE ANN. (Throckmorton, 1940) \$5546-2.

${ }^{3}$ See Wahrhaftig, Meaning of Retail Sale and Storage, Use or Other Consumption, infra this issue.

4 I Williston, Sales (2d ed. 1924) 54, 55.

${ }^{5}$ See W. VA. Code Ann. (Michie and Sublett, 1937) $\$ \$ 999(3)$ ) $999(8)$, $999(2)$ (applics to "all services except professional and personal services"); OHro CODE ANN. (Throckmorton, 1940) \$5546-2 
the majority either make a specific exclusion, or exclude by reason of their statutory or common-law definition of a "sale." Services which are entirely divorced from any transfer of ownership of property are, therefore, clearly not subject to the tax. The difficult problem arises in the case of those services which as an incident thereto also involve a transfer of property. The wording of the statutes is certainly broad enough to include such transfers, but both tax commissions and courts have adopted a more restricted interpretation. ${ }^{6}$ Surely no one would contend that, when a barber shaves a person, the application of shaving soap and lotion should be taxed as a sale. Nor, on the other hand, is it contended that a deduction should be made from the sale price of gasoline purchased because of the window-wiping service of the attendant. But these are cases where the sale or the service element is merely incidental. Other cases lie in between. They are probably best approached by an analysis of specific fact situations in which the problem has arisen.

In the professions and allied groups, the doctor, the dentist, the lawyer, or the optometrist is clearly not within the statute, if no tangible property is transferred. But when the doctor puts a metal brace on a broken leg, the dentist prepares a set of false teeth, the lawyer draws an abstract of title, or the optometrist delivers a pair of glasses, one is faced with a more difficult situation. The problem is neatly presented by the dispute over the taxability of the optometrist. Illinois has held that the optometrist is not liable for any tax, as the sale of glasses, even though a factor in determining the total price, is merely incidental and necessary to the furtherance of the professional service rendered. ${ }^{7}$ The court stressed the professional requirements of education and training, ${ }^{8}$ and the fact that a reputation is established not because of the quality of the merchandise furnished, but rather as a result of the ability shown in the service rendered. The optometrist was compared to the physician who incidentally furnishes medicines, braces or surgical dressings, or the dentist with whom the by-product of skill is inlays and dentures. ${ }^{9}$

The majority of jurisdictions, ${ }^{10}$ however, have held the optometrist taxable at least for the sale price of the glasses, though they concede that there is no tax on the professional service. It is pointed out that classification of optometry as a profession under state optometry laws does not preclude the possibility that the optometrist

(exempts "professional, insurance, or personal service transactions which involve sales as inconsequential elements"). Because of the limited nature of the services included, these could hardly be called gross reccipts taxes.

'Suci an interpretation may run counter to uniformity clauses of some state constitutions, which, as in Winter v. Barrett, 352 Ill. $44 x$, I 86 N. E. II3 (x933), have been held to require that all persons engaged in the business of selling tangible personal property must be included in the tax.

${ }^{7}$ Babcock v. Nudelman, 367 Ill. 626, r2 N. E. (2d) 635 (1937).

${ }^{8}$ These requirements are remarkably similar to those of a master plumber; see, e.g., IlL. REv. STAT. (Bar Ass'n Ed., 1939) c. III $1 / 2, \$ \$ 95 \mathrm{et} \mathrm{seq.} \mathrm{Is} \mathrm{the} \mathrm{plumber,} \mathrm{therefore,} \mathrm{also} \mathrm{exempt} \mathrm{from} \mathrm{taxation?}$

${ }^{\circ}$ See Berry-Kofran Dental Laboratory Co. v. Smith, 345 Mo. 922, I37 S. W. (2d) 452 (I940); Axelrod-Beacon Dental Laboratory v. City of Philadelphia, 34 D. \& C. 190 (Pa. Com. Pl. I938). Compare the common law which has held that a contract for the sale of false teeth by a dentist is a contract to sell within the Statute of Frauds. Lee v. Griffen, I B. \& S. 272 (Ex. I 86r).

${ }^{10}$ State Tax Comm. v. Hopkins, 234 Ala. 556, I76 So. 2 I0 (I937); Kamp v. Johnson, 15 Cal. (2d) 187, 99 P. (2d) 274 (1940); Commonwealth v. Miller, 337 Pa. 246, II A. (2d) 14I (r940). 
makes a "sale" under the definition in the taxing act. While some courts say the relative value of the materials, twenty per cent, to the services rendered is of no significance, it is nevertheless probably influential. The optometrist makes an actual transfer of title to tangible personal property. Such a transfer properly belongs to the occupation of the optician who is taxable, ${ }^{11}$ and not to that of an optometrist. If the optometrist invades the optician's field of business as a vendor of merchandise, he cannot then claim immunity from the imposition of a tax merely because he happens also to be engaged in the profession of optometry.

The pharmacist in preparing prescriptions has, despite his allegations of professional character, been held taxable even in Illinois. ${ }^{12}$ The basis of the tax is usually the total selling price of the prescription, rather than the twenty-five to fifty per cent which represents materials. This is an easier case than that of the optometrist, because of this larger proportion of property to services, and also because of the public's attitude that it is purchasing prescribed drugs rather than the service of a pharmacist. Attempts by undertakers ${ }^{13}$ to evade a tax on the sale of caskets and shrouds because of state regulation of their business have also been unsuccessful, though they are not taxed on the service rendered.

Many other kinds of tangible personal property derive their chief value from the labor expended in their manufacture. Yet, this alone is not sufficient to create a tax exemption. The actual cost of the canvas and pigment may be infinitesimal in comparison with the value of the work wrought by a Rembrandt's genius. The cost of the yarn used in a rug may be quite negligible in comparison with the value added by the artistry of the weaver. Yet the sale of the Rembrandt or the Oriental rug is taxable, as is the manufacture of products involving a lesser labor element. ${ }^{14}$

While theoretically the repair trades may effect a sale of the materials used in connection with their service, the courts have taken a more practical approach. Usually they have come to consistent results. The important criteria have been two: first, the relative importance of the value of the tangible personal property ordinarily used in conjunction with this type of repair work as compared with the total charge therefor; and, second, the trade practice customarily followed, before the tax was levied, in connection with billing in that occupation. This second criterion is much preferable to one based on the practice of the particular tradesman, or the method of billing in the particular transaction, since the taxpayer should not be allowed to evade the tax by manipulating the form but not the substance of the transaction. The point has been stressed that here the work is on property belonging to another. The slight amount of new materials added by the repairman becomes a part of the

${ }^{11}$ See Ill. Ret. Occ. Tax Rules and Reg. (1939) Rule 32; N. Y. City Sales Tax Reg. (1939) art. 74.

12 Wray's Pharmacy v. Lee, 199 So. 767 (Fla. 1941) (the statute included "any services which are a part of such sale"); Appeal of Biser, 317 Pa. 190,176 Atl. 200 (1935); Ill. Ret. Occ. Tax Rules and Reg. (1939) Rule I2; see Dep't of Treasury v. Ridgely, 2II Ind. 9, 4 N. E. (2d) 557 (1936). Cf. Mich. Sales Tax Reg. (r940) Rule 57, which taxes only 50 per cent of the total charge, if a record of the prescription is kept.

${ }^{23}$ Ahern v. Nudelman, 374 Ill. 237 , 29 N. E. (2d) 268 (1940); Kistner v. Iowa State Board, 225 Iowa 404, 280 N. W. 587 (1938); Commonwealth v. Dennien, 320 Pa. 257, I82 Atl. 542 (1936).

${ }^{14}$ See Bigsby v. Johnson, 99 P. (2d) 268 (Cal. 1940); Appeal of Biser, supra note I2. 
customers' property not by a process of sale, but rather through the doctrine of accession.

Textile and fur cleaners, dyers and repairers, watch repairers, and laundries have all been held not to make "sales." 15 Auto repairers" ${ }^{16}$ are not taxable on transfers of paints, lubricants, or minor supplies; but they must pay the tax on sales of auto accessories and parts, where material costs are high and the trade practice in billing has consistently been to itemize labor and materials. Shoe repairing has presented a close question. The largeness of the proportion of materials to service, over thirty per cent, must be counterbalanced against the accounting difficulty of determining the amount of leather going into each repair, and the trade practice of lump sum billing. The prevailing view ${ }^{17}$ is that the shoe repairer does make a "sale." An Iowa decision, ${ }^{18}$ originally going to the contrary, was modified on rehearing so that as to taps and rubber heels, where the service element is small and there is competition with retail stores subject to tax, the transfer from the shoe repairer to the customer is taxable. Illinois ${ }^{10}$ solves the bookkeeping difficulty by providing that in the absence of evidence to the contrary, tax will be collected on one-third of the total receipts from shoe-repair work.

The problem of installation charges ${ }^{20}$ is treated a good deal like that of repair. Probably the decisive criteria are the same: the proportion of merchandise cost to services, and the trade practice followed in billing. Illinois, ${ }^{21}$ however, taxes the installation cost only if the seller is required to install the property in order to complete the sales contract. This again presents some risk of a manipulation of form to escape taxation.

Despite conflicting common-law rules ${ }^{22}$ as to whether or not serving food and drink in a restaurant constitutes a sale for the purpose of imposing an implied warranty of fitness, the courts ${ }^{23}$ have held in the affirmative for the purpose of the taxing act. This is one instance where common-law decisions are of dubious value in deciding sales tax cases. Here future doctrinal developments may hold in store the reverse effect of sales tax decisions influencing the doctrine of implied warranty in restaurant cases.

${ }^{16}$ In re H. D. Kampf, Inc., 38 F. Supp. 319 (S. D. N. Y. 194I); Walter Mahon v. Nudelman, Sup. Ct. of Cook County, Ill., Nov. 8, 1940 (unreported); Marshall v. Ames, 373 Ill. 38 I, 26 N. E. (2d) 483 (1940); Matter of Mendoza v. Taylor, 272 N. Y. 275, 5 N. E. (2d) 818 (I936).

${ }_{10}$ Doby v. State Tax Comm., 234 Ala. 150, 174 So. 233 ' (1937).

${ }^{17}$ See Revsan v. Nudelman, 370 Ill, I80, I8 N. E. (2d) 219 (1938); H. H. Atkinson Co. v. State, Circuit Ct. of Wayne County, Mich., April, 1934 (unreported); Western Leather and Finding Co. v. State Tax Comm., 87 Utah 227, 48 P. (2d) 526 (1935).

${ }^{18}$ Sandberg Co. v. Iowa State Board, 225 Iowa ro3, 278 N. W. 643 (1938), modified on rehearing, 225 lowa III, 28I N. W. 197 (I938). ${ }^{19}$ Ill. Ret. Occ. Tax Rules and Reg. (1939) Rule I3.

${ }^{20}$ Fifteenth Street Inv. Co. v. People, ro2 Colo. 57I, 8x P. (2d); 764 (1938); American Molasses Co. v. MeGoldrick, 256 App. Div. 649, II N. Y. S. (2d) 289 (1939); Commonwealth v. Pennsylvania Heat and Power, 333 Pa. 46, 3 A. (2d) 412 (1939); Commonwealth v. Miller, 337 Pa. 246, II A. (2d) I4I (1940). ${ }^{21}$ Ill. Ret. Occ. Tax Rules and Reg. (r939) Rule 64.

${ }_{22}$ McCarley v. Wood Drugs, 228 Ala. 226, 153 So. 446 (1934) (no sale for warranty purposes); Greenwood v. John R. Thompson Co., 213 Ill. App. 37 I (1919) (serving food does constitute a sale); I Williston, op. cit. supra note 4 , at 485 .

${ }^{33}$ Pappanastos v. State Tax Comm., 235 Ala. 50, I77 So. 158 (1937); State Tax Comm. v. Burns, 236 Ala. 307, I82 So. I (I938); Breevort Hotel v. Ames, 360 Ill. 485 , Ig6 N. E. 46 I (I935). 
The courts are sharply divided as to the applicability of the sales tax to occupations such as printing, engraving, photography, etc. A minority of jurisdictions, led by Illinois in Burgess v. Ames, ${ }^{24}$ make a distinction between work done on special order without value to any person other than the immediate purchaser, and that done which has general commercial value. Despite the Illinois court's refusal to give weight to common-law precedents, this distinction is probably based on the Massachusetts common-law rule ${ }^{25}$ that contracts of the former type were for labor and materials, and not for a sale. This rule was carried over into the Uniform Sales Act to exclude from the operation of the Statute of Frauds manufactured goods for which there is no market aside from the individual purchaser. The printer, the courts say, has no absolute property right capable of transfer either in the copy presented to him, or in the product when finished. If it is a lawyer's brief, the title remains in the lawyer. The small amount of paper and ink which has been transferred has had its commercial value destroyed by the printing process, and now has worth only as a brief. What the customer really pays for is not the paper and ink, but rather the skill and labor of the printer, and the use of his machinery and equipment.

That this service element is any the less important when a complicated form is printed for a limited class of the general public, as compared to a simple letterhead printed by the millions for a large corporation, is certainly not easy to demonstrate. Difficulty also occurs as to the taxability of sales of supplies to the printer ${ }^{26}$ when even the printer does not know at the time of the purchase which of the supplies will be used for a tax-free transfer, since on special order, and which as a taxable sale, since of general commercial value. Complete exemption of the entire series of transactions from tax may be the most practical solution. These difficulties need not spread to custom-built autos or clothing, ${ }^{27}$ unless the peculiarity of the design definitely makes them without general commercial value.

Probably the majority of jurisdictions, ${ }^{28}$ however, hold printing and the allied arts subject to sales tax. In their judgment, the controlling factor is that the customer, even if giving a special order, desires not a service, but rather the delivery of a finished product. This factor distinguishes these cases from the professional work and repair exemptions, where the primary desire in most instances is the service, rather than the material. The proportion in value of the materials used to the service performed is of little importance, especially since it varies with the number of units

24 359 Ill. 427 , 194 N. E. 565 (1935) (blueprinting and photostatic copying); sec also Adair Printing v. Ames, 364 Ill. 342,4 N. E. (2d) 635 (1936) (printing); A. B. C. Electrotype v. Ames, 364 Ill. 360 , 4 N. E. (2d) 476 (r936) (electrotyping and stereotyping); Baker v. Tax Comm., Ohio Com. Pl., Cuyahoga County, April 4, r940 (unseported) (printing); Washington Printing and Binding Co. v. State, 192 Wash. 448,73 P. (2d) 1326 (1937) (printing). ${ }_{25}^{25}$ Williston, op. cit. stipra note 4, at 50.

${ }^{28}$ See Acme Printing Co. v. Nudelman, 37I Ill. 217, 20 N. E. (2d) 277 (I939) (sale of ink to printer held taxable).

${ }_{37}$ See Ill. Ret. Occ. Tax Rules and Reg. (1939) Rule 30.

${ }^{28}$ Long v. Roberts \& Son, 234 Ala. 520, 176 So. 213 (1937) (commercial printing; dissent on basis of the Illinois decisions); Bigsby v. Johnson, supra note r4 (printing); Cusick v. Commonwealth, 260 Ky. 204, 84 S. W. (2d) I4 (1935) (commercial photography); People ex rel. Walker Engraving Co. v. Graves, 268 N. Y. 648 , 198 N. E. 539 (1935) (engraving); see Typecrafters, Inc. v. City of Philadelphia, 34 D. \& C. 82 (Pa. Com. Pl. 1938). 
produced. Moreover, a taxable sale has been found ${ }^{29}$ in the transfer of engraved plates valued at not more than two per cent of the purchase price. ${ }^{30}$

In summary, litigation has revealed some four factors which will be considered by most courts in determining the taxability of tangible personal property transferred in conjunction with a service rendered: first, the percentage of value of the property transferred to the total charge collected; second, the primary desire of the usual purchaser in entering into the transaction, whether to obtain materials of good quality or to secure a skillful service individualized to his needs; third, the ease with which the same article, in like quantity, may be obtained from some taxable source; and fourth, the established trade practice in billing. Judgments under these criteria are difficult to make. Except under the first factor, in cases falling within the rule of de minimis, no one factor will itself be determinative. It is likely, furthermore, that these criteria do run counter to the tax exemption given by the minority of jurisdictions to the optometrist, and to the printer working on special orders.

\section{Sale by Another Name}

Further, there are the situations which, because of the lack of a transfer of legal title, are not, strictly speaking, "sales," but which are nevertheless specifically included in the statutes of certain states. ${ }^{31}$ A too literal regard for this language is often unwarranted. The courts ${ }^{32}$ have frequently held that the legislators did not mean what literally they had enacted, but rather inserted the added language to cover an attempted tax evasion by making a "sale" under some other guise.

Transactions whereby the possession of the property is transferred but the seller retains the title merely as security for payment of the selling price, are always held to be taxable as "sales."33 "Leases and rentals" of tangible personalty are covered by some statutes expressly, ${ }^{34}$ by others through implication, ${ }^{35}$ and by some not at all..$^{36}$ In any jurisdiction, however, when a contract for rental, lease, or bailment is in fact a contract to sell such property, as evidenced by the fact that the lessee or bailee agreed to pay an amount substantially equivalent to the purchase price, or had the option of becoming the owner by complying with contract terms, the subterfuge will be struck aside and a tax collected. ${ }^{37}$

${ }^{20}$ People ex rel. Walker Engraving Co. v. Graves, supra note 28.

${ }^{30} \mathrm{~A}$ compromise solution for this class of cases is suggested by Voss v. Gray, 298 N. W. I (N. D. I94I). It was there held that where a photographer makes two charges-one for the sitting, whether or not the photographs are delivered, and a second if and when they are-the sales tax applies only to the latter. But where only one charge is made, or the splitting of the charge is not in good faith, the tax is applicable to the entire price.

${ }^{31}$ See, e.g., Mrch. Stat. Ans. (Henderson, I936) $\$ 752($ b) ; New York City Local Laws 1939, No. IoI, $\$ N_{4}$ I-I.O(5). The wording of these and similar statutes is discussed later.

${ }^{32}$ Howitt v. Street \& Smith Publications, 276 N. Y. 345, 12 N. E. (2d) 435 (1938); Western Machinery Co. v. Johnson, Cal. Super. Ct., Sept. 28, 1939 (unreported); see CaI. Gen. LAws (Deering, I938) $\$ 8493-2(c)$.

${ }^{33}$ ILL. Rev. Stat. (Bar Ass'n Ed., r939) c. 120, \$440.

34 Cal. Gen. Laws (Deering, I938) \$8493-2(b); W. VA. Code ANN. (Michic and Sublett, 1937) \$999(2) 4; Onro CODE ANN. (Throckmorton, I940) $\$ 5546-1$.

${ }_{35}$ New York City Local Laws r939, No. ror, \$N $4 \mathrm{I}-\mathrm{I.0}(5)$.

${ }^{\text {ac }}$ See Ill. Ret. Occ. Tax Rules and Reg. (I939) Rule r6. 
Of great interest is a series of cases in New York and Pennsylvania limiting the extent of their statutory definition of "sale," which includes "any transfer of title or possession or both, ... license to use or consume or otherwise, in any manner or by any means whatsoever."38 In the leading case of Howitt v ${ }_{4}$ Street \& Smith Publications, $^{39}$ a publisher paid an artist a consideration for the right to reproduce sixteen of the artist's paintings on the covers of the publisher's magazines. Possession of the paintings was temporarily given to the publisher, who sent them to a photo-engraver. The court, saying that the definition was only an "attempt to cover a situation where parties might attempt to call a sale by another name," held that this right to reproduce was not a "sale." The court stressed the fact that the photo-engraver could as well have made the reproduction while the drawing was still in the artist's possession in his studio, and that the transfer of possession was therefore merely incidental. In an earlier case ${ }^{40}$ a designer created several paper sketches which were then traced on copper rolls, and through these fabric was run for the purpose of imprinting the design on the cloth. Unlike the paintings in the Howitt case, the sketches became the property of the manufacturer; the transaction was accordingly held taxable as a "transfer of title and possession" rather than as a "license to use."

In Dun \& Bradstreet $\nu$. City of New York, ${ }^{41}$ the delivery by a credit agency to its subscribers of possession to reference books, worth possibly seventy-five per cent of the total charge, was, on motion to dismiss, held not taxable as a "license to use." The reference books were considered to be merely incidental to the rendering of a service; nor was the possession of the customer complete inasmuch as he was expected to keep the information private and return the books at the termination of the contract, or whenever a new edition was published. To achieve a dubious consistency with the Howitt case, the Appellate Division, in its later decision, ${ }^{42}$ pointed out that the possession of the books need not have been transferred at all, since the subscriber could secure any of the information contained in them by a visit to the office of the credit-rating agencies. More recently, ${ }^{43}$ the sale of books and pamphlets containing financial information, published periodically and furnished as an information service, was held subject to tax. While absence of an opinion makes judgment hazardous, the case may be distinguished from the Dun \& Bradstreet decision since unrestricted title to these books and pamphlets probably was transferred to the subscriber.

A commercial photographer ${ }^{44}$ by express reservation retained title to prints and graphic illustrations, but transferred the possession thereof to his customers for advertising purposes. That the substantial fee charged by the photographer was paid for the right to reproduce, rather than for the particular print or illustration, is shown

${ }^{38}$ N. Y. City Local Laws 1939, No. ror, $\$ N_{4} 1-1.0(5)$ (ital. added); Philadelphia City Laws 1938 , Sales Tax Ord., §rd. ${ }_{80} 276$ N. Y. 345,12 N. E. (2d) 435 (1938).

${ }^{\circ 0}$ People ex rel. Foremost Studios v. Graves, 264 App. Div. 130, 284 N. Y. Supp. 906 (1936).

41276 N. Y. I98, II N. E. (2d)' 728 ( 1937 ) (decided on the complaint).

42 I68 Misc. 215,5 N. Y. S. (2d) 597 (1938) (decided on the facts proved at trial).

${ }^{43}$ Moody Investors Service v. McGoldrick, 280 N. Y. 58I, 20 N. E. (2d) 35 (1938) (two dissents on the basis of the Dun \& Bradstreet decision).

"Andersen v. City of New York, 172 Misc. 370, 15 N. Y. S. (2d) 155 (1939). 
by the fact that if the print was lost, or the customer wanted another, he could secure the same for a nominal fee. On the basis of the Howitt case, this right to reproduce was held not to be a "license to use or consume," and therefore not taxable. ${ }^{45}$

In view of these New York cases restricting the "license to use" clause, the case of United Artists Corp. $v$. Taylor, ${ }^{46}$ decided before the Howitt case and holding taxable a license to exhibit motion picture films, may be questionable. The case can, of course, be distinguished, since the license to exhibit, without the transfer of possession, which was for a definite period, would be valueless. A Louisiana decision, ${ }^{\mathbf{4 7}}$ with comparable statutory language to construe, felt that the United Artists case was still good law, despite later New York cases, and therefore reached the same result.

Under the similar Philadelphia ordinance, ${ }^{48}$ the opinions seem to adopt the broader interpretation of "license to use." A linen supply house has been held taxable, ${ }^{49}$ because the right to possession was necessary to the use and was transferred for a sufficient length of time to come within the Howitt case, even though title to the linen remained in the supply house. As to typesetters, a distinction is made, based on the person purchasing the type-metal. ${ }^{50}$ If the printer purchases the metal, then the typesetter renders only services. If, however, the type-metal is furnished by the typesetter, and loaned on a deposit charge to the printer, though no charge is ultimately made for anything but the service in either case, then the entire transaction is deemed taxable because of the transfer of the "license to use." Even if one is to adopt the broader construction of these cases, its application may be questioned in this type of situation where no charge whatsoever is made for the so-called "license to use."

\section{Sale for Other than Money or Profit}

The courts have been almost uniform in holding that the profit motive is not essential to the creation of a taxable "sale."51 A California decision,"52 however, has held that a social club incidentally furnishing meals to its members was not in the "business" of selling. The intervening passage of an amendment, specifically taxing club transactions, influenced this conclusion. The Pennsylvania view ${ }^{53}$ holding clubs subject to the tax is preferable. A gas company selling gas appliances at cost in order

\footnotetext{
45 Burgess v. Ames, 359 Ill. 427, I94 N. E. 565 (1935), more easily reached the same result with a statute not containing the "right to use" clause.

${ }^{10} 273$ N. Y. 334,7 N. E. (2d) 254 (1937).

${ }^{17}$ Saenger Realty Corp. v. Grosjean, I94 La. 470, I93 So. 7ro (I940).

${ }^{4}$ Cited supra note 38 .

${ }^{10}$ Philadelphia Ass'n of Linen Suppliers v. City of Philadelphia, 139 Pa. Super. 560, 12 A. (2d) 789 (1940). Contra: Ohio Sales Tax Reg. (I939) Rule r22.

50 Typecrafters, Inc. v. City of Philadelphia, supra note 28. Contra: Ill. Ret. Occ. Tax Rules and Reg. (I939) Rule 36.

¿x Stone v. Rogers, 186 Miss. 53, I89 So. 81o (1939); Bay City v. State Board, 292 Mich. 24I, 290

N. W. 395 (1940).

a3 Union League Club v. Johnson, 108 P. (2d) 487 (Cal. I940).

os Wilson v. City of Philadelphia, $330 \mathrm{~Pa} .342$, r98 Atl. 889 (I938).
} 
to stimulate gas consumption has been held taxable. ${ }^{54}$ And a retailer taking merchandise from stock for his own use, ${ }^{55}$ has also been held accountable for the sales tax, since otherwise, it is argued, he has an unfair advantage over his neighbors. If the retailer were not taxable, then the wholesaler, as to this merchandise, would be making a sale at retail; but any attempt to trace this sale back to the wholesaler would be administratively ineffective. It has also been held ${ }^{56}$ that there is no tax on a foreclosure sale to the mortgagee under a chattel mortgage, since the sale does not transfer title, but merely extinguishes the mortgagor's equity of redemption.

Nor need a sale be for money in order to fall within the sales tax act; it need only be "for a valuable consideration." Such a consideration includes in addition to money the value of any merchandise given or service rendered in exchange for property. Barter transactions, therefore, are taxable, at least to the party engaged in business, if not to both. ${ }^{57}$ Trade-ins are generally taxed on the basis of the allowed rather than the actual value. ${ }^{58}$ A trifle inconsistently, food served to restaurant employees as part payment for their services is not taxable. ${ }^{59}$ This is probably in accord with the common conception of what constitutes a sale, and administratively is a practical result; yet a logical argument could be made that the services rendered by the employees were a "valuable consideration" for which the food was transferred.

\section{The Nature of Tangible Personal Property}

The sales tax applies to the sale of "tangible personal property." Because most statutes do not contain a workable definition, the distinctions between tangible and intangible property, personalty and realty, are usually the same as those of the common law. Tangibles consist of things or substances which may be touched, felt, or observed; things that are "perceptible, palpable, capable of being possessed or realized."Bo Intangibles, which are not taxable, include shares of stock, bonds, corporate or other franchises, evidences of interest in property, evidences of indebtedness, and the like. Services, already discussed, might well be considered intangible, as well as rights to use, to consume, to reproduce, etc. Some few additional problems deserve special attention.

While it requires little argument to establish that electricity, gas, steam, and water are tangible within any definition of that term, much can be said for the contention that a statute referring to sales of tangible personal property is not intended to include them. It has also been questioned ${ }^{61}$ whether the compulsory furnishing of

${ }^{5}$ Lee v. Jacksonville Gas Co., I38 Fla. 890, 19o So. 800 (1939).

${ }^{56}$ Mann v. McCaroll, I98 Ark. 628, 130 S. W. (2d) 721 (I939).

${ }^{E 6}$ Prudential Ins. Co. of America v. McGoldrick, 256 App. Div. 205, 9 N. Y. S. (2d) 515 (1939).

${ }^{87}$ Stone v. Rogers, supra note $5 \mathrm{r}$.

${ }^{58}$ Montgomery Ward \& Co. v. Fry, 277 Mich. 260, 269 N. W. x66 (x936); Missouri v. Hallen. berg-Wagner Motor Co., 34I Mo. 771, 108 S. W. (2d) 398 (x937); cf. Ill. Ret. Occ. Tax Rules and Reg. (1939) Rule 15, which taxes trade-ins only on the basis of cash actually received on later sale of property traded in. See generally, Ratchford, The Measure of Consumption Taxes, infra this issue.

${ }^{6}$ In re Messinger's Merchants Lunch Room, 85 F. (2d) 1002 (C. C. A. 7th, 1936); State Tax Comm. v. Burns, 236 Ala. 307,182 So. I (I938).

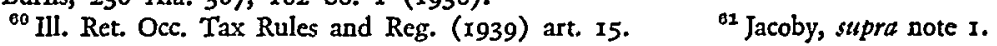


such commodities at government-controlled rates to customers who have no option but to buy can properly be called a "sale" at all, as that term is commonly used. In the absence of a usual statutory provision, the courts are divided as to taxability. ${ }^{62}$ An interesting case arose as to the sale of steam from a central heating plant. ${ }^{63}$ If the steam is delivered to the consumer, who subsequently uses the water condensed therefrom, it was said to be taxable. But if such a transaction take the form of a delivery of heat units through a radiating system, with the steam or condensed water returning to the vendor or allowed to run down a sewer, the opposite conclusion was held to follow, probably because of the intangible nature of heat units.

Newspapers, characteristically, have felt that they should be in a specially favored class, and were, therefore, disturbed when Bigsby $v$. Johnson ${ }^{64}$ held them subject to the sales tax. Their contention is that as they do not really sell anything tangible, but rather sell their services and convey intangible information which possesses only temporary value, they should not, therefore, be taxed. But certainly there is a transfer of tangible paper, and it has general commercial value at least for the day.

As sales taxes apply only to personal property, the sale of land, and of buildings and other permanent improvements to land, are consequently all free from taxation. But what of a case ${ }^{65}$ where $A$, the owner of a farm, leases a gravel pit on his farm to $B$, who is building a road? Under the agreement the rental is fixed at fifteen cents per yard of gravel removed. Gravel, while in its original bed, is as much a part of the realty as the earth itself. But once separated from the land it becomes tangible personalty. When placed in the roadbed, it again reassumes its character as real property. The determination of taxability may depend on an interpretation of the terms of the agreement. If the owner is selling all of the gravel in a specified tract of land, the sale is a sale of real property, even though payment may depend on the amount of gravel removed. On the other hand, if the owner is merely agreeing to sell such gravel as may be taken from the land, or a certain number of yards of gravel at a specified price per yard, the sale is a sale of gravel when and as it is separated from the land. In the first case no tax is collectible, while in the second there is a tax, unless this be an isolated or casual sale.

In Swain Nelson \& Sons Co. v. Dep't of Finance ${ }^{68}$ a nurseryman unsuccessfully attempted to evade the Illinois retailers' occupation tax. He argued that trees and shrubbery are real property at the time a contract is made, and since they must be growing in the purchasers' soil before the terms of the contract are fulfilled, no

\footnotetext{
02 People's Gas Light and Coke Co. v. Ames, 359 Ill. II2, I94 N. E. 260 (1934), held that the legislative intent was against such taxation, though later in People v. Menagas, 367 IIl. 330 , II N. E. (2d) 403 (1937), it was held that electricity was tangible property and therefore subject to larceny. Wiseman v. Arkansas Utilities Co., I9r Ark. 854, 88 S. W. (2d) 81 (1935), declared that since the sale of natural gas was made expressly subject to the tax, sales of artificial gas were impliedly exempt, notwithstanding that the act provided that the tax applied to all sales of tangible personal property. Bay City v. State Board, stupra note $5 \mathrm{I}$, held public utilities taxable.

${ }^{63}$ Detroit Edison Co. v. Fry, Circ. Ct. Wayne County, Mich., March, 1934 (unreported).

os Supra note 14.

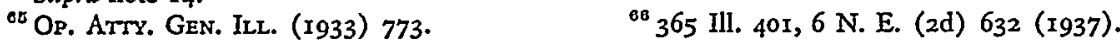


transfer of personal property takes place. The court, refusing to give any weight to common-law and Uniform Sales Act decisions, held that since the trees and shrubs are personal property when severed for transportation, title passes at that time, and there is, therefore, a sale of personal property within the taxing act.

This distinction between personalty and realty receives its most frequent application in the case of contractors. The trend today is definitely towards holding such contractors outside the scope of the sales tax. ${ }^{67}$ The arguments made are two: First, that this is not a sales contract at all but a contract for work and materials. This is a questionable argument in view of the large material cost, and the customer's attitude that he is paying for a finished job rather than the contractor's services. Second, that the contract is not to deliver materials and fixtures as such, but rather to deliver the finished building or other structure which is realty and not personalty. By the doctrine of accession, the materials furnished, when attached to the realty, become part of the realty, and thereby lose their identity as personal property. It should not make any difference that the contract is on a time and material basis, rather than for a lump sum. The amount charged includes labor and material costs plus profits, and is the same in either case. A distinction is drawn in Illinois ${ }^{68}$ between "materials," such as gravel and steel beams, which lose their identity in the completed structure and therefore are not taxable, and "fixtures," such as bath tubs and radiators, which do not lose their identity when installed, and therefore are taxable. This differentiation has caused endless difficulty in application and has little logical basis. The recent Illinois decision in Materials Service Corp. $v$. Nudelman, ${ }^{60}$ now on appeal, will, if affirmed, resolve this difficulty by giving the transfer from the contractor complete exemption from the sales tax. ${ }^{70}$

An argument that an undertaker ${ }^{71}$ was not selling tangible personal property, but rather was using the caskets and converting the same into real property by burial in the ground, was answered by holding that title to the caskets passed as of the date of signing the contract rather than at burial, thus making the sale one of personalty. A similar argument as to gravestones ${ }^{72}$ was also overthrown.

\footnotetext{
${ }^{67}$ Lone Star Cement Co. v. State Tax Comm., 234 Ala. 465, 75 So. 699 (1937); Materials Service Corp. v. Nudelman, Circ. Ct. Cook County, Ill., Feb. I4, I94I (appeal being taken); Herlihy Mid-Continent Co. v. Nudelman, 367 Ill. 600 , I2 N. E. (2d) 638 (1938); State v. Christhilf, 170 Md. 586 , I85 Atl. 456 (I936); Acorn Iron Works v. State Board, 295 Mich. I43, 295 N. W. 126 (1940); Albuquerque Lumber v. Bureau of Revenue, 45 N. M. 58, 75 P. (2d) 334 (1940).

Contra: Bradley Supply Co. v. Ames, 359 Ill. 162, 194 N. E. 272 (1935) (distinguished in the Herlihy case, and repudiated in the Materials Service case); Blome Co. v. Ames, 365 Ill. 457, 6 N. E. (2d) $84 \mathrm{I}$ (1937) (overruled by the Herlihy case); Moore v. Pleasant Harbor Const. Co., 50 Ariz. 317, 72 P. (2d) 573 (1937) (based on the Bradley and Blome cases); Wiseman v. Gillioz, 192 Ark. 950, 96 S. W. (2d) $459(\times 936)$.

${ }^{\circ 8}$ See Ill. Ret. Occ. T'ax Rules and Reg. (1939) Rule 6, based on Bradley Supply Co. v. Ames, stuprat note 67. ${ }^{60}$ Supra note 67 .

${ }^{70}$ If the contractor be held not liable, is he therefore to be considered the ultimate consumer so that the sale from the material man to him is taxable as a sale at retail of tangible personal property? This and analogous problems are considered by Wahrhaftig, supra note 3 .

${ }^{71}$ Kistner v. Iowa State Board, suspra note 13.

${ }^{72}$ Goldstein Monument Works, Inc. v. Graves, 254 App. Div. 798, 4 N. Y. S. (2d) 241 (1938).
} 
In conclusion a few generalizations may be made. While the wording of each statute must be carefully noted, there is a tendency for the courts to base decisions on their conception of the general nature of a sales transaction, and, therefore, to use similar reasoning even in different jurisdictions under different taxing acts. Commonlaw and Uniform Sales Act decisions, despite the frequent statements of the courts to the contrary, are often of value. The tendency is for the court to watch for the administrative practicability of differing solutions, whenever it does not feel too strongly one way or another. The need for revenue, in a tax originally passed as an emergency fund-raising measure, is probably considered. In addition to the inconsistencies in the same situations apparent as between jurisdictions, there is frequently little consistency within each jurisdiction in the treatment of differing fact situations. However, the sales tax is a new taxing device. It can well be expected that, as the court decisions become more numerous, they will also become more uniform in their definition of the taxable transaction. 